\title{
In Vivo Small-Animal PET/CT of EphB4 Receptors Using ${ }^{64} \mathrm{Cu}$-Labeled Peptide
}

\author{
Chiyi Xiong ${ }^{1}$, Miao Huang ${ }^{1}$, Rui Zhang ${ }^{1}$, Shaoli Song ${ }^{1,2}$, Wei Lu ${ }^{1}$, Leo Flores II $^{1}$, Juri Gelovani ${ }^{1}$, \\ and Chun $\mathrm{Li}^{1}$ \\ ${ }^{1}$ Department of Experimental Diagnostic Imaging, University of Texas M.D. Anderson Cancer Center, Houston, Texas; and \\ ${ }^{2}$ Department of Nuclear Medicine, Renji Hospital, Shanghai Jiaotong University, School of Medicine, Shanghai, China
}

\begin{abstract}
Many solid tumors overexpress EphB4 receptor, a member of the ephrin receptor tyrosine kinase family. Noninvasive imaging of EphB4 could potentially increase early detection rates, monitor response to therapy directed against EphB4, and improve patient outcomes. The purpose of this study was to evaluate a novel ${ }^{64} \mathrm{Cu}$-labeled peptide with high receptor binding affinity for PET of EphB4 receptors. Methods: The EphB4-binding peptide TNYLFSPNGPIARAW (TNYL-RAW) was conjugated with fluorescein isothiocyanate (FITC) and DOTA. DOTA-TNYL-RAW was labeled with ${ }^{64} \mathrm{Cu}$ with high labeling efficiency. The binding affinity of TNYL-RAW and its derivatives to purified recombinant EphB4 was determined using surface plasmon resonance technology. In vitro binding of both FITC-TNYL-RAW and ${ }^{64} \mathrm{Cu}$-DOTA-TNYL-RAW to cancer cells was assessed by fluorescent microscopy and a radioactivity count method. In vivo biodistribution and small-animal $\mathrm{PET} / \mathrm{CT}$ were performed in mice bearing EphB4-expressing CT26 and PC-3M tumors as well as EphB4-negative A549 tumors. Results: TNYL-RAW and its derivatives displayed high binding affinity to EphB4, with equilibrium dissociation constant of 1.98-23 nM. In vitro, both FITC-TNYL-RAW and ${ }^{64} \mathrm{Cu}$-DOTATNYL-RAW were selectively taken up by CT26 and PC-3M cells but not by A549 cells. Binding of FITC-TNYL-RAW and ${ }^{64} \mathrm{Cu}-$ DOTA-TNYL-RAW to CT26 and PC-3M cells could be blocked by an excess amount of TNYL-RAW. In vivo, ${ }^{64} \mathrm{Cu}$-DOTA-TNYLRAW showed significantly higher uptake in PC-3M tumors than in A549 tumors, with percentages of injected dose per gram of tumor of $0.84 \pm 0.09$ and $0.44 \pm 0.09$ at $24 \mathrm{~h}$ after radiotracer injection, respectively. Small-animal PET/CT clearly revealed deposition of ${ }^{64} \mathrm{Cu}$-DOTA-TNYL-RAW in CT26 and PC-3M tumors but not in A549 tumors. Furthermore, uptake of ${ }^{64} \mathrm{Cu}$ DOTA-TNYL-RAW in both CT26 and PC-3M tumors could be blocked by cold TNYL-RAW. Conclusion: The expression of EphB4 receptors can be noninvasively interrogated by smallanimal PET/CT using ${ }^{64} \mathrm{Cu}$-DOTA-TNYL-RAW.
\end{abstract}

Key Words: EphB4 receptors; peptide; ${ }^{64} \mathrm{Cu}$; positron emission tomography

J Nucl Med 2011; 52:241-248

DOI: 10.2967/jnumed.110.081943

\footnotetext{
Received Aug. 4, 2010; revision accepted Nov. 9, 2010

For correspondence or reprints contact: Chun Li, Department of Experimental Diagnostic Imaging-Unit 59, University of Texas M.D. Anderson Cancer Center, 1515 Holcombe Blvd., Houston, TX 77030.

E-mail: cli@mdanderson.org

COPYRIGHT @ 2011 by the Society of Nuclear Medicine, Inc.
}

$\mathbf{O}$ ver the past 2 decades, various radiolabeled peptides have been developed as nuclear imaging agents for tumor detection and noninvasive assessment of receptor expression in solid tumors. For example, small radiolabeled somatostatin peptidyl analogs with a molecular weight of approximately $1.5 \mathrm{kDa}$ have been successfully used in the clinic for localizing neuroendocrine tumors expressing somatostatin receptors $(1,2)$. Cyclic Arg-Gly-Asp peptide that strongly binds to integrin $\alpha_{v} \beta_{3}$ receptors is currently under clinical investigation (3). Several other peptide-based imaging agents, including melanocyte-stimulating hormone ana$\log (4)$, substance P (5), calcitonin (6), atrial natriuretic peptide (7), bombesin/gastrin-releasing peptide, cholecystokinin, glucagonlike peptide-1, and neuropeptide-Y, have also been identified and characterized for tumor receptor imaging (8). Despite these efforts, peptides that can be used for the noninvasive detection of prostate and colon cancer remain elusive (8). These peptide-based imaging agents could potentially increase rates of early detection of prostate and colon cancer, thus improving patient outcomes.

The ephrin receptors are the largest family of receptor tyrosine kinases (9). They are divided into an EphA and an EphB class that bind to glycosylphosphatidylinositol-linked ephrin-A ligands and the transmembrane ephrin-B ligands, respectively. EphB4 receptors play important roles in a variety of biologic processes, including cell aggregation and migration, neural development, embryogenesis and angiogenesis, and vascular development (10-13). EphB4 selectively binds to its endogenous ligand, ephrin-B2, to promote cell signaling required for cancer progression and angiogenesis and has been shown to be profoundly upregulated in numerous cancer types, such as prostate, colon, lung, gastric, bladder, ovarian, and breast cancers (14-20). Overexpression of EphB4 in cancer cells is associated with tumorigenesis and angiogenesis by stimulating reverse signaling through ephrin-B2. EphB4 forward signaling, on the other hand, has been shown to inhibit cellular proliferation (11). The widespread expression of EphB4 in tumors has stimulated interest in exploring the development of new cancer therapeutic agents that target this receptor 
$(16,21,22)$. However, to date, no imaging agent has been developed for the detection of EphB4 in cancer cells.

Recently, Koolpe et al. (23) identified, using phage display technology, several 12-mer peptides that selectively bind to individual ephrin receptors. Tyr-Asn-Tyr-LeuPhe-Ser-Pro-Asn-Gly-Pro-Ile-Ala (TNYLFSPNGPIA), an EphB4-binding peptide from the initial screening, was further modified to include a RAW moiety at the carboxyl terminus on the basis of alignment with a segment corresponding to the ephrin-B2 G-H loop. The resulting peptide, Tyr-Asn-Tyr-Leu-Phe-Ser-Pro-Asn-Gly-Pro-Ile-Ala-Arg-AlaTrp (TNYLFSPNGPIARAW, designated as TNYL-RAW), was shown to be a potent antagonist of EphB4, with a 50 percent inhibition concentration of approximately $15 \mathrm{nM}$ for the binding of ephrin-B2 to murine EphB4 receptors.

Here we investigated whether TNYL-RAW can be used as a receptor ligand for the noninvasive imaging of EphB4. Our data show that ${ }^{64} \mathrm{Cu}$-labeled TNYL-RAW is a promising radiotracer for PET of EphB4 receptor expression in both human prostate and colon cancer xenograft models. To the best of our knowledge, this is the first demonstration of noninvasive imaging of EphB4 using small-molecularweight peptides.

\section{MATERIALS AND METHODS}

\section{Materials}

The general procedure for the peptide synthesis is presented in the supplemental information (available online only at http://jnm. snmjournals.org). ${ }^{64} \mathrm{Cu}$ was produced on a CS-15 biomedical cyclotron at Washington University School of Medicine. Recombinant EphB4/Fc chimera, phycoerythrin-conjugated rat antihuman EphB4 monoclonal antibody, and rabbit anti-EphB4 antibody were purchased from Santa Cruz Biotechnology. Goat antirabbit antibody conjugated with near-infrared dye was purchased from Li-COR. The protein assay kit was obtained from Bio-Rad. DOTA was obtained from Macrocyclics. The Biacore sensor chip CM5, amine coupling kit, HBSEP running buffer (0.01 M 4-(2-hydroxyethyl)1-piperazineethanesulfonic acid [HEPES], $\mathrm{pH} 7.4 ; 0.15 \mathrm{M} \mathrm{NaCl}$; $3 \mathrm{mM}$ ethylenediaminetetraacetic acid [EDTA]; and $0.005 \%$ [v/v] surfactant P20 solution), and regeneration buffer were purchased from Biacore, Inc. 4',6-diamidino-2-phenylindole (DAPI) was obtained from Sigma-Aldrich.

\section{Radiolabeling of DOTA-TNYL-RAW}

${ }^{64} \mathrm{CuCl}_{2}(74-148 \mathrm{MBq}$ [2-4 mCi]) in $0.1 \mathrm{M}$ sodium acetate $(\mathrm{pH}$ 5.2) was added to $10 \mu \mathrm{g}$ of DOTA-TNYL-RAW in water. The reaction mixture was incubated at $70^{\circ} \mathrm{C}$ for $1 \mathrm{~h}$. The progress of the reaction was monitored by reversed-phase high-performance liquid chromatography (RP-HPLC) with a radiodetector. The reaction was terminated with the addition of EDTA. The ${ }^{64} \mathrm{Cu}$-labeled peptide was further purified, if necessary, by RP-HPLC on an Agilent 1100 system (C-18, Vydac; $4.6 \times 250 \mathrm{~mm}, 10 \mu \mathrm{m})$ eluted with a linear gradient of $10 \%-90 \%$ acetonitrile in a $0.1 \%$ aqueous trifluoroacetic acid solution over $35 \mathrm{~min}$ at a flow rate of $1.0 \mathrm{~mL} / \mathrm{min}$. ${ }^{64} \mathrm{Cu}$-DOTA-TNYL-RAW (retention time, $12.5 \mathrm{~min}$ ) was collected in 1- to $2-\mathrm{mL}$ fractions. The solvent was then removed, reconstituted in saline, and passed through a $0.22-\mu \mathrm{m}$ filter for use in the animal experiments. Natural copper chloride $\left({ }^{\text {nat }} \mathrm{CuCl}_{2}\right)$ was used to synthesize nat $\mathrm{Cu}-\mathrm{DOTA}-\mathrm{TNYL-RAW}$ under identical conditions, and its identity was confirmed by high-resolution electrospray ionization mass spectrometry. ${ }^{64} \mathrm{Cu}$-DOTA-TNYL-RAW was coinjected with nat $\mathrm{Cu}$-DOTA-TNYL-RAW into the HPLC system, which was equipped with both ultraviolet and radiodetectors to confirm its identity.

\section{Stability of Radiolabeled ${ }^{64} \mathrm{Cu}$-DOTA-TNYL-RAW}

${ }^{64} \mathrm{Cu}$-DOTA-TNYL-RAW was incubated in Dulbecco's modified Eagle's medium (DMEM) containing 10\% fetal bovine serum (FBS) or mouse serum at $37^{\circ} \mathrm{C}$. Aliquots were removed at $1,2,4$, 6,12 , and $24 \mathrm{~h}$ and analyzed by RP-HPLC with a radiodetector to assess their stability.

\section{Immobilization of EphB4 Receptor to Sensor Chip}

The stock solution $(100 \mu \mathrm{g} / \mathrm{mL})$ of EphB4/Fc in phosphatebuffered saline (PBS) was diluted to $25,12.5$, and $6.25 \mu \mathrm{g} / \mathrm{mL}$ with $10 \mathrm{mM}$ sodium acetate buffer at $\mathrm{pH} 4.5$ and immobilized to a CM5 sensor chip using the amine-coupling reaction following manufacturer-provided procedures (Biacore, Inc.). Briefly, the surfaces of the chips in flow cells $1,2,3$, and 4 were activated by exposing them to a mixture of $200 \mathrm{mM} N$-ethyl- $N^{\prime}$-dimethylaminopropyl carbodiimide and $50 \mathrm{mM} N$-hydroxysuccinimide for 7 min. Flow cell 1 was used as a reference surface and was directly deactivated by injecting $1 \mathrm{M}$ ethanolamine at $\mathrm{pH} 8.5$ for $7 \mathrm{~min}$. The other 3 flow cells were injected with 25, 12.5, and $6.25 \mu \mathrm{g}$ of EphB4/Fc per milliliter, followed by $1 \mathrm{M}$ ethanolamine to block the remaining activated ester groups on the surface. The chip was allowed to stabilize for at least $2 \mathrm{~h}$ in HBSEP running buffer before test analytes were injected.

\section{Surface Plasmon Resonance (SPR) Assay of Receptor Binding Affinity}

Binding assays were performed at $25^{\circ} \mathrm{C}$ in HBSEP running buffer. The peptides were diluted in HBSEP buffer, filtered, degassed, and injected at concentrations between 1.6 and 800 $\mathrm{nM}$ at a flow rate of $30 \mu \mathrm{L} / \mathrm{min}$. The injection time of peptides into the HBSEP buffer was $4 \mathrm{~min}$, followed by a 4-min dissociation period. The chips were regenerated using a 1-min pulse of 10 $\mathrm{mM}$ glycine ( $\mathrm{pH} 2.2$ ) after each binding circle. Each cycle consisted of a 1-min waiting period to allow monitoring of the baseline binding stability. For subtraction of bulk effects caused by changes in the buffer composition or nonspecific binding, we performed double referencing. Thereby, all analyzed samples were additionally injected onto an uncoated reference surface, including a sample of the running buffer, which was also tested on the EphB4/Fc-coated flow cell. Data were evaluated with BIAevaluation software (version 3.0; Biacore, Inc.), applying a simple 1:1 binding mass transfer model. The obtained sensorgrams were fitted globally over the whole range of injected concentrations for both the association and the dissociation phases. Equilibrium dissociation constants $\left(\mathrm{K}_{\mathrm{D}}\right)$ were then calculated from the dissociation and association rate constants ( $\mathrm{k}_{\mathrm{off}}$ and $\mathrm{k}_{\mathrm{on}}$, respectively) (24).

\section{Fluorescence Microscopy}

The CT26 murine colon cancer cell line and A549 human lung adenocarcinoma epithelial cell line were purchased from the American Type Culture Collection. The PC-3M human prostate cancer cell line was obtained from Dominic Fan (M.D. Anderson Cancer Center). PC-3M, CT26, or A549 cells were seeded $(1 \times$ $10^{5} /$ well) in Lab-Tek II-chambered slides (Nalge Nunc International) supplemented with RPMI 1640 medium plus 10\% FBS $1 \mathrm{~d}$ 
before the experiment. The cells were incubated with $100 \mu \mathrm{L}$ of phenol-free RPMI 1640 culture medium containing $10 \mu \mathrm{M}$ FITC-TNYL-RAW or scrambled FITC-scTNYL-RAW (AGPFNTYLRINAWSP) for $20 \mathrm{~min}$ at room temperature. For the blocking experiment, $10 \mu \mathrm{M}$ FITC-TNYL-RAW and $1 \mathrm{mM}$ TNYL-RAW were added to the cells. For detection of EphB4 expression, cells were incubated with $10 \mu \mathrm{L}$ of phycoerythrin-conjugated rat antihuman anti-EphB4 monoclonal antibody (R\&D Systems) in $100 \mu \mathrm{L}$ of phenol red-free RPMI 1640 medium. The cells were washed and fixed with $4 \%$ paraformaldehyde for $15 \mathrm{~min}$ at room temperature. The cell nuclei were counterstained with DAPI. After washing with PBS, the slides were mounted and visualized under an Axiovert Z.1 fluorescent microscope (Zeiss).

\section{Cell Binding}

For the cell binding study, CT26, PC-3M, and A549 cells were grown in 6-cm Petri dishes as described before (25). The culture medium was replaced with $2 \mathrm{~mL}$ of RPMI 1640 without FBS containing ${ }^{64} \mathrm{Cu}-\mathrm{DOTA}-\mathrm{TNYL}-\mathrm{RAW} \quad(\sim 1.48 \mathrm{MBq} / \mathrm{mL} \quad[\sim 40$ $\mu \mathrm{Ci} / \mathrm{mL}], 100 \mathrm{nM}$ ), and cells were incubated at room temperature for 30, 60, or $120 \mathrm{~min}$. For the blocking experiment, ${ }^{64} \mathrm{Cu}$-DOTATNYL-RAW peptide $(\sim 1.48 \mathrm{MBq} / \mathrm{mL}[\sim 40 \mu \mathrm{Ci} / \mathrm{mL}], 100 \mathrm{nM})$ was coincubated with TNYL-RAW $(10 \mu \mathrm{M})$ under the same conditions. Thereafter, the monolayers were scraped and transferred into 5-mL tubes. The tubes were briefly stirred in a vortex mixer, and $100 \mu \mathrm{L}$ of the cell suspension were transferred into a microcentrifuge tube containing $500 \mu \mathrm{L}$ of a 75:25 mixture of silicon oil (density, 1.05; Sigma-Aldrich) and mineral oil (density, 0.872; Acros). The mixture was centrifuged at $14,000 \mathrm{rpm}$ for $5 \mathrm{~min}$. After the tubes were frozen in liquid nitrogen, the bottom tips containing the cell pellet were cut off. The cell pellets and supernatants were counted with a Packard Cobra Quantum $\gamma$-counter (GMI). The protein content in a $100-\mu \mathrm{L}$ cell suspension was quantified using the Bio-Rad protein assay kit according to the manufacturer's protocol. The radioactivity in the cell pellets and medium was counted, and the data were expressed as activity ratios of the cell pellet to the medium ([counts $/ \mathrm{min} / \mu \mathrm{g}$ of protein in pellet $] /[$ counts $/ \mathrm{min} / \mu \mathrm{g}$ of medium]). The experiments were performed in pentaplicate.

\section{Animal Models}

All animal studies were performed under the guidelines and approval of the Institutional Animal Care and Use Committee. Athymic nude mice (4-6 wk old, both sexes) were obtained from Harlan Laboratories. CT26, PC-3M, and A549 cells were grown in DMEM/F12 supplemented with $10 \%$ FBS, penicillin (100 IU/ $\mathrm{mL})$, and streptomycin $(100 \mu \mathrm{g} / \mathrm{mL})$ (Invitrogen) at $37^{\circ} \mathrm{C}$ in a humidified atmosphere with $5 \% \mathrm{CO}_{2}$. The cells were harvested by trypsinization. After centrifugation of the cell suspension at $5,000 \mathrm{rpm}$ for $5 \mathrm{~min}$, the culture medium was aspirated and the cell pellet was resuspended in culture medium for subcutaneous injection in the right front leg of each mouse. When tumors were about $1 \mathrm{~cm}$ in diameter, small-animal PET/CT and biodistribution analysis were performed.

\section{Small-Animal PET/CT}

Mice bearing PC-3M tumors $(n=4)$, CT26 tumors $(n=4$; EphB4-positive), or A549 tumors $(n=4$; EphB4-negative) were imaged with small-animal PET/CT at various times after intravenous injection of $7.4 \mathrm{MBq}(200 \mu \mathrm{Ci})$ of ${ }^{64} \mathrm{Cu}$-DOTA-TNYLRAW $(0.5-1 \mu \mathrm{g})$. For the blocking experiment, the tumor-bearing mice $(n=2)$ were coinjected with $7.4 \mathrm{MBq}(200 \mu \mathrm{Ci})$ of ${ }^{64} \mathrm{Cu}-$
DOTA-TNYL-RAW and cold TNYL-RAW peptide at a dose of 50 $\mu \mathrm{g} / \mathrm{mouse}$. Images were acquired using an Inveon PET/CT system (Siemens). The spatial resolution of the PET system is approximately $1.4 \mathrm{~mm}$. Tumor-bearing mice were anesthetized with isoflurane ( $2 \%$ in oxygen) and placed prone. The CT parameters were as follows: $\mathrm{x}$-ray voltage, $80 \mathrm{kVp}$; anode current, $500 \mathrm{~mA}$; and exposure time of each of the 360 rotational steps, 300-350 ms. Images were acquired at 1,4 , and $24 \mathrm{~h}$ after intravenous administration of ${ }^{64} \mathrm{Cu}$-DOTA-TNYL-RAW. Images were reconstructed using the 2-dimensional ordered-subsets expectation maximization algorithm. PET and CT image fusion and image analysis were performed using Inveon Research Workplace (Siemens Preclinical Solutions). For tumor voxel intensity calculation, an irregular 3-dimensional region of interest (ROI) was manually drawn covering the whole tumor on $\mathrm{CT}$ and then copied to the corresponding PET images. A circular ROI $\left(\sim 20 \mathrm{~mm}^{3}\right)$ was drawn on the muscle of the legs. An ROI was also drawn on a standard (radiotracer solution containing $1 \%$ of the injection dose) placed along with the animals. The mean activities within the ROI of the tumor and muscle were calculated in an IRW workstation (Siemens).

\section{Assessment of Biodistribution by Tissue Sampling}

In a separate experiment, athymic nude mice bearing PC-3M, CT26, and A549 xenografts ( $n=4$ /group) were injected with 0.74 $\mathrm{MBq}(20 \mu \mathrm{Ci}, 50 \mathrm{ng})$ of ${ }^{64} \mathrm{Cu}$-DOTA-TNYL-RAW peptide to evaluate the biodistribution of the radiotracer. For the blocking experiment, the tumor-bearing mice $(n=2)$ were coinjected with $0.74 \mathrm{MBq}(20 \mu \mathrm{Ci})$ of ${ }^{64} \mathrm{Cu}$-DOTA-TNYL-RAW and 200-fold cold TNYL-RAW peptide. The animals were sacrificed at 4 and $24 \mathrm{~h}$ after injection. The organs of interest were excised and weighed and their radioactivity counted using an automatic $\gamma$-counter (GMI). The stomach and intestines were not emptied before radioactivity measurements. The percentage of injected dose per gram of tissue $(\% \mathrm{ID} / \mathrm{g})$ was calculated by dividing the $\%$ ID organ by the weight of the organ. Values were expressed as mean $\pm \mathrm{SD}$.

\section{Immunohistochemical Analysis}

After the small-animal PET/CT studies were completed, the mice were sacrificed and their tumors were excised, snap-frozen, and cut into $4-\mu \mathrm{m}$ sections. For immunohistochemical analysis, frozen tumor sections were fixed in $4 \%$ paraformaldehyde solution for $20 \mathrm{~min}$ at room temperature and washed with PBS 3 times. Tumor sections were blocked with $10 \%$ goat serum for $30 \mathrm{~min}$ at $37^{\circ} \mathrm{C}$, and the slides were then incubated with rabbit anti-EphB4 antibody (U-200, 1:100 dilution) in PBS at $37^{\circ} \mathrm{C}$ overnight. After incubation with primary antibody, slides were washed with PBS 3 times and incubated with secondary goat antirabbit antibody conjugated with Alexa Flour 488 (1:500 dilution; Invitrogen). Slides were washed again in PBS and counterstained with DAPI. Microphotographs were taken under a Zeiss Axiovert Z.1 fluorescence microscope with the same conditions and displayed at the same scale to make sure that the relative brightness observed in the images reflected the difference in EphB4 expression level.

\section{RESULTS}

\section{Chemistry, Radiochemistry, and Stability}

The structure of ${ }^{\text {nat }} \mathrm{Cu} /{ }^{64} \mathrm{Cu}$-DOTA-TNYL-RAW is shown in Figure 1. The reaction scheme for the synthesis of ${ }^{\text {nat }} \mathrm{Cu} /{ }^{64} \mathrm{Cu}$-DOTA-TNYL-RAW is shown in Supplemental Figure 1A. RAW was eluted as a single peak with a 


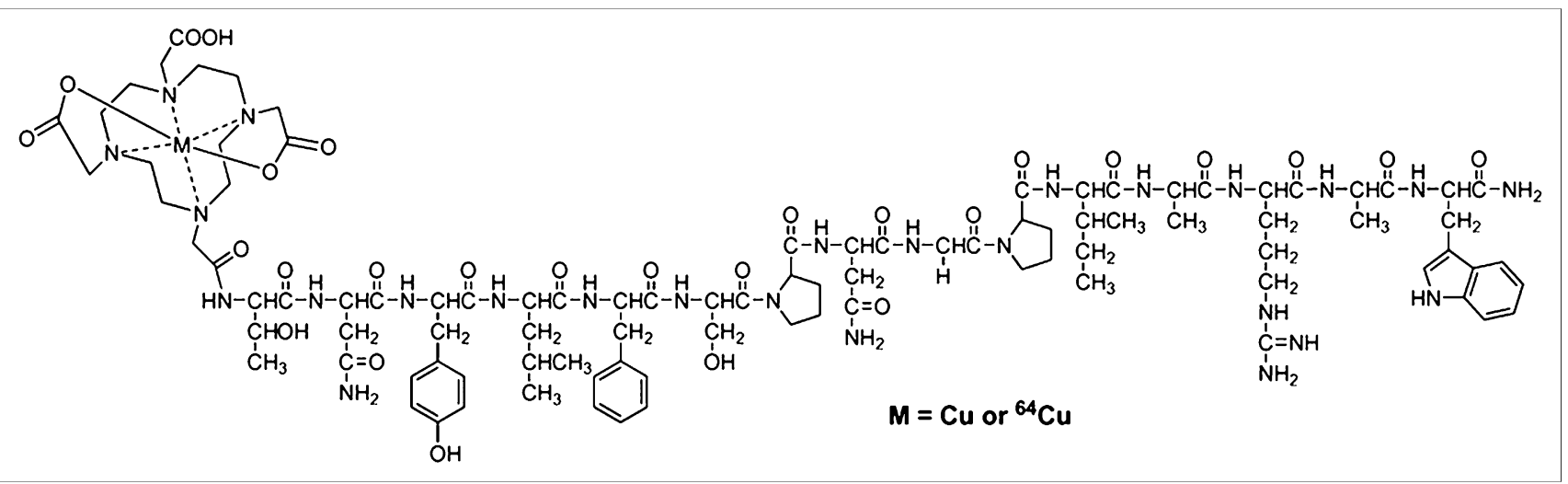

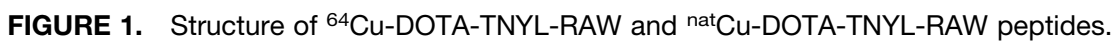

retention time of $13.8 \mathrm{~min}, \mathrm{~m} / \mathrm{z}=1,705.7764$ for $[\mathrm{M}+\mathrm{H}]^{+}$ $\left(\mathrm{C}_{80} \mathrm{H}_{117} \mathrm{~N}_{22} \mathrm{O}_{20}\right.$, calculated [M+H] ${ }^{+}:$1,705.8814). DOTATNYL-RAW was eluted as a single peak with a retention time of $12.6 \mathrm{~min}, \mathrm{~m} / \mathrm{z}=2,092.0554$ for $[\mathrm{M}+\mathrm{H}]^{+}$ $\left(\mathrm{C}_{96} \mathrm{H}_{143} \mathrm{~N}_{26} \mathrm{O}_{27}\right.$, calculated $\left.[\mathrm{M}+\mathrm{H}]^{+}: 2,092.0616\right)$. FITCTNYL-RAW was eluted as a single peak with a retention time of $15.6 \mathrm{~min}, \mathrm{~m} / \mathrm{z}=2,094.9003$ for $[\mathrm{M}+\mathrm{H}]^{+}$ $\left(\mathrm{C}_{101} \mathrm{H}_{128} \mathrm{~N}_{23} \mathrm{O}_{25} \mathrm{~S}\right.$, calculated $[\mathrm{M}+\mathrm{H}]^{+}:$2,094.9172).

The formation of the ${ }^{\text {nat }} \mathrm{Cu}$ (II)-labeled complex ${ }^{\text {nat }} \mathrm{Cu}$ DOTA-TNYL-RAW was confirmed by mass spectrometry (Supplemental Fig. 1B), with $\mathrm{m} / \mathrm{z}=1,076.9957$ for $[\mathrm{M}+\mathrm{Cu}]^{2+}\left(\mathrm{C}_{96} \mathrm{H}_{143} \mathrm{CuN}_{26} \mathrm{O}_{27}\right.$, calculated $[\mathrm{M}+\mathrm{Cu}]^{2+}$ : 1,076.9917). Under the same HPLC conditions, ${ }^{\text {nat }} \mathrm{Cu}-$ DOTA-TNYL-RAW (ultraviolet detector) and ${ }^{64} \mathrm{Cu}-$ DOTA-TNYL-RAW (radiodetector) had almost identical retention times (12.5 and $12.6 \mathrm{~min}$, respectively) (Supplemental Fig. 1C). The radiochemical purity, defined as the ratio of the main product peak to all peaks, was determined by HPLC to be more than $95 \%$. The specific activity of ${ }^{64} \mathrm{Cu}$-DOTA-TNYL-RAW used in the in vitro and in vivo experiments was typically $7.4-14.8 \mathrm{MBq} / \mathrm{nmol}(0.2-0.4 \mathrm{Ci} /$ $\mu \mathrm{mol})$ at the end of synthesis. ${ }^{64} \mathrm{Cu}$-DOTA-TNYL-RAW was stable in DMEM containing 10\% FBS for up to $24 \mathrm{~h}$ at $37^{\circ} \mathrm{C}$. Approximately $30 \%$ of the ${ }^{64} \mathrm{Cu}$-DOTA-TNYLRAW was degraded after $2 \mathrm{~h}$ of incubation in mouse serum at $37^{\circ} \mathrm{C}$.

\section{Binding of TNYL-RAW Peptides to EphB4 Receptors with $\mathrm{nM}$ Affinity}

Figure 2 shows representative sensorgrams obtained from SPR analyses of ${ }^{\text {nat }} \mathrm{Cu}$-DOTA-TNYL-RAW and a scrambled peptide, with fitting curves obtained using a global 1:1 mass transfer model (red lines). SPR sensorgrams of TNYL-RAW and DOTA-TNYL-RAW peptides are presented in Supplemental Figure 2. The corresponding binding kinetics and affinity data are summarized in Table 1. TNYL had a $\mathrm{K}_{\mathrm{D}}$ of $3.06 \mathrm{nM}$. Conjugation of DOTA to the $\mathrm{N}$ terminus of the peptide increased the $\mathrm{K}_{\mathrm{D}}$ value to 23.3 nM. Chelation of $\mathrm{Cu}^{2+}$ to DOTA-TNYL-RAW restored the binding affinity of the resulting metal complex, with a $\mathrm{K}_{\mathrm{D}}$ value of $1.98 \mathrm{nM}$. No binding to EphB4 was detected with a scrambled peptide (AGPFNTYLRINAWSP).

\section{Selective Binding of FITC-TNYL-RAW to Tumor Cells Overexpressing EphB4 In Vitro}

Two EphB4-positive cell lines (PC-3M and CT26) and 1 EphB4-negative cell line (A549) were used for an in vitro binding study. Immunohistostaining with phycoerythrinconjugated rat antihuman EphB4 monoclonal antibody confirmed the expression of EphB4 on the surface of PC-3M (Fig. 3) and CT26 and A549 cells (Supplemental Fig. 3). PC-3M and CT26 cells, but not A549 cells, were readily stained with FITC-TNYL-RAW. An FITC-labeled scrambled TNYL-RAW peptide (FITC-sc-TNYL-RAW) did not show

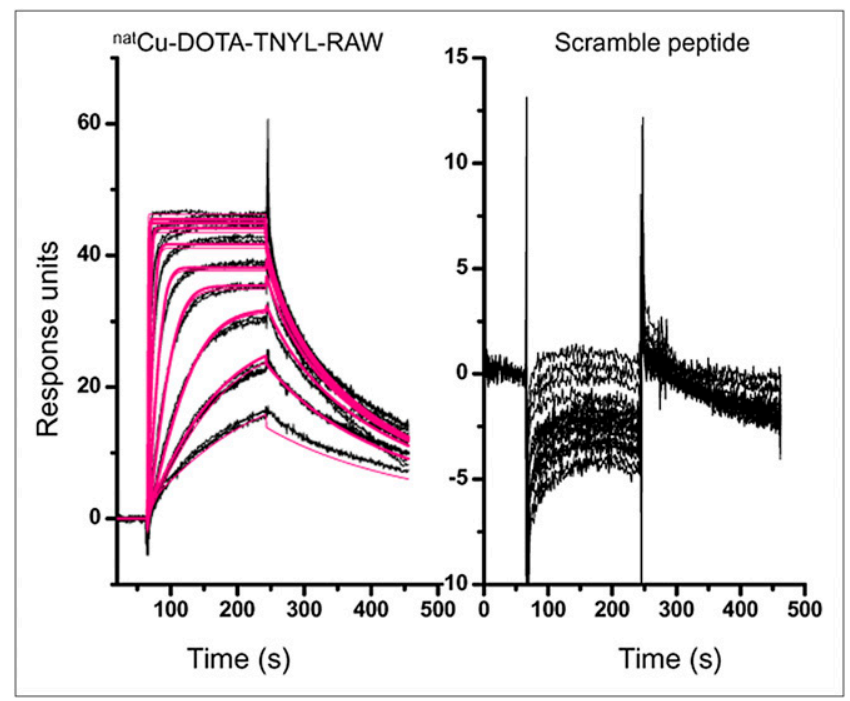

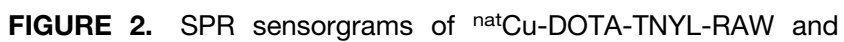
scrambled peptide on sensor chips coated with EphB4. Peptides were injected as ten 2-fold concentration series from 1.6 to $800 \mathrm{nM}$ and were analyzed in duplicate binding cycles. Datasets (shown in black) are overlaid with curves fit to 1:1 mass transfer interaction model (red lines). Vertical axes in response units represent binding of each peptide to immobilized EphB4. 
TABLE 1

Association and Dissociation Rates and $K_{D}$ of Peptides Interacting with Immobilized EphB4 Receptors Obtained from SPR Analysis

\begin{tabular}{ccccc}
\hline Analyte & $\begin{array}{c}\mathrm{k}_{\text {on }} \\
\left(\mathrm{M}^{-1} \mathrm{~s}^{-1}\right)\end{array}$ & $\begin{array}{c}\mathrm{k}_{\text {off }} \\
\left(\mathrm{s}^{-1}\right)\end{array}$ & $\begin{array}{c}\mathrm{K}_{\mathrm{D}} \\
(\mathrm{M})\end{array}$ & $\chi^{2}$ \\
\hline TNYL-RAW & $4.26 \times 10^{5}$ & $1.3 \times 10^{-3}$ & $3.06^{-9}$ & 0.155 \\
DOTA-TNYL-RAW & $1.10 \times 10^{5}$ & $2.56 \times 10^{-3}$ & $2.33^{-8}$ & 0.281 \\
natCu-DOTA- & $6.89 \times 10^{6}$ & $1.31 \times 10^{-2}$ & $1.98^{-9}$ & 1.86 \\
TNYL-RAW & & & &
\end{tabular}

$\mathrm{k}_{\mathrm{off}}=$ dissociation rate constant; $\mathrm{k}_{\mathrm{on}}=$ association rate constant.

detectable binding to PC-3M and CT26 cells. The binding of FITC-TNYL-RAW to PC-3M and CT26 cells could be efficiently blocked by an excess amount of unlabeled TNYL-RAW peptide (Fig. 3A; Supplemental Fig. 3).

\section{Selective Binding of ${ }^{64} \mathrm{Cu}$-DOTA-TNYL-RAW Peptide to EphB4-Positive Cells}

${ }^{64} \mathrm{Cu}$-DOTA-TNYL-RAW had increased uptake with time in EphB4-positive PC-3M and CT26 cell lines but not in EphB4-negative A549 cells. Coincubation with cold TNYL-RAW peptide completely abolished the binding of ${ }^{64} \mathrm{Cu}$-DOTA-TNYL-RAW to PC-3M at all time points tested (Fig. 3B) and reduced its binding to CT26 cells by approximately 10-fold (Supplemental Fig. 4).

\section{Small-Animal PET/CT}

Figure 4 shows small-animal PET/CT of both coronal and transverse slices that contain tumor. Tumors were clearly visualized at 1 and $4 \mathrm{~h}$ (CT26) and at 4 and $24 \mathrm{~h}$ (PC-3M) after the ${ }^{64} \mathrm{Cu}$-DOTA-TNYL-RAW injection. In contrast, A549 tumors were barely discernible after radiotracer injection. The uptake of ${ }^{64} \mathrm{Cu}-\mathrm{DOTA}-\mathrm{TNYL}-\mathrm{RAW}$ in
CT26 tumors was rapid, reaching 1.3 and $2.6 \% \mathrm{ID} / \mathrm{g}$ at $1 \mathrm{~h}$ and $4 \mathrm{~h}$ after injection, respectively. By $24 \mathrm{~h}$ after injection, the level of tumor radioactivity had declined to the body background level (Fig. 4). The uptake values of ${ }^{64} \mathrm{Cu}-$ DOTA-TNYL-RAW in PC-3M tumors were 1.4, 3.2, and $3.6 \% \mathrm{ID} / \mathrm{g}$ at 1,4 , and $24 \mathrm{~h}$ after injection, respectively. The accumulation of ${ }^{64} \mathrm{Cu}$-DOTA-TNYL-RAW in A549 tumors was low at all time points examined, reaching a level of 1.7 , 1.5 , and $1.2 \% \mathrm{ID} / \mathrm{g}$ at 1,4 , and $24 \mathrm{~h}$ after radiotracer administration. These values were only slightly higher than those recorded for muscle tissue in the same animals. Ex vivo immunohistochemical staining confirmed the expression of EphB4 throughout the CT26 and PC-3M tumors, whereas A549 tumors did not express EphB4 receptors (Supplemental Fig. 5).

Figure 5 compares small-animal PET images obtained in the presence and absence of a large excess of cold TNYLRAW at $4 \mathrm{~h}$ after radiotracer injection in a CT26 tumorbearing mouse and at $24 \mathrm{~h}$ after radiotracer injection in a PC-3M tumor-bearing mouse. In CT26 and PC-3M tumor models, the coadministration of cold TNYL-RAW caused a respective $77 \%$ and $81 \%$ reduction in ${ }^{64} \mathrm{Cu}$-DOTA-TNYLRAW accumulation in tumors.

\section{Biodistribution of ${ }^{64} \mathrm{Cu}-$ DOTA-TNYL-RAW Assessed by Tissue Sampling}

Biodistribution of ${ }^{64} \mathrm{Cu}$-DOTA-TNYL-RAW at $24 \mathrm{~h}$ after radiotracer injection in nude mice bearing $\mathrm{PC}-3 \mathrm{M}$ prostate and A549 lung cancer xenografts is summarized in Figure 6A. There was significantly higher uptake of ${ }^{64} \mathrm{Cu}$-DOTATNYL-RAW in PC-3M than in A549 tumors $(0.84 \% \mathrm{ID} / \mathrm{g}$ vs. $0.44 \% \mathrm{ID} / \mathrm{g}, \mathrm{SD}=0.09$ and 0.09 , respectively, $P=$ 0.000015). The liver, spleen, and kidneys were the major organs with highest radiotracer retention (Fig. 6A). The tumor-to-muscle ratio was reduced $56.7 \%$ in CT26 tumors at $4 \mathrm{~h}$ after injection and $47.6 \%$ in PC-3M tumors at $24 \mathrm{~h}$

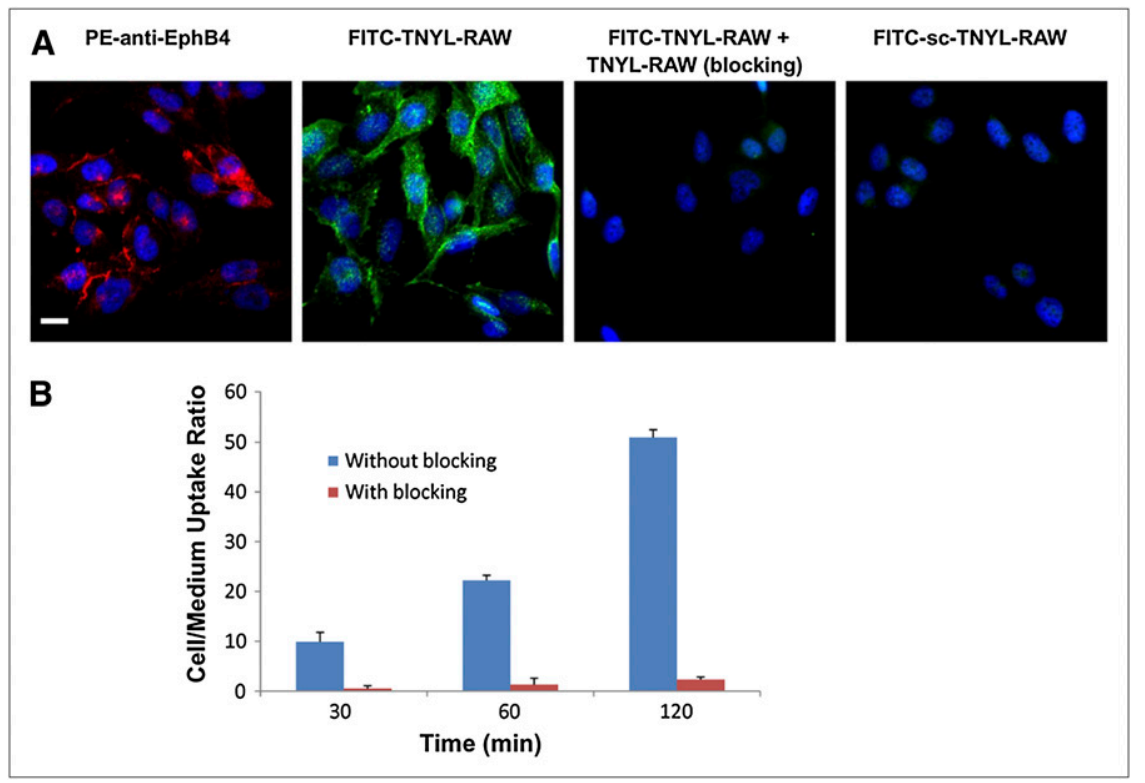

FIGURE 3. (A) Fluorescence photomicrographs of PC-3M cells treated with FITCTNYL-RAW (10 $\mu \mathrm{M}$, green) or scrambled peptide FITC-sc-TNYL-RAW (10 $\mu \mathrm{M}$, green) for $20 \mathrm{~min}$ at room temperature. Cells were also stained with phycoerythrin-conjugated anti-EphB4 antibody (red) for expression of EphB4 receptors. For blocking experiment, FITC-TNYL-RAW $(10 \mu \mathrm{M})$ was coincubated with TNYL-RAW (1 mM). Cell nuclei were counterstained with DAPI (blue). Bar $=20$ $\mu \mathrm{m}$. (B) Uptake of ${ }^{64} \mathrm{Cu}-\mathrm{DOTA}-\mathrm{TNYL}-\mathrm{RAW}$ in EphB4-expressing PC-3M cells. Cell-tomedium uptake ratio is expressed as (counts/ $\mathrm{min} / \mu \mathrm{g}$ of protein in pellet)/(counts $/ \mathrm{min} / \mu \mathrm{g}$ of medium). ${ }^{64} \mathrm{Cu}$-DOTA-TNYL-RAW exhibited increased uptake over time in PC-3M cells. This uptake was blocked by parent TNYL-RAW peptide. PE = phycoerythrin. 


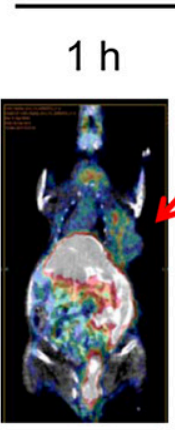

$4 \mathrm{~h}$ $24 \mathrm{~h}$
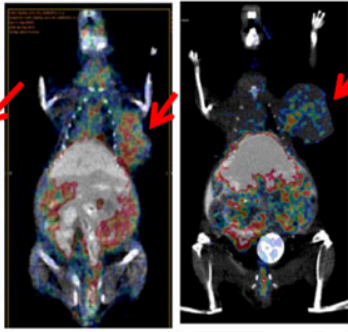

$1 \mathrm{~h}$

$4 \mathrm{~h}$
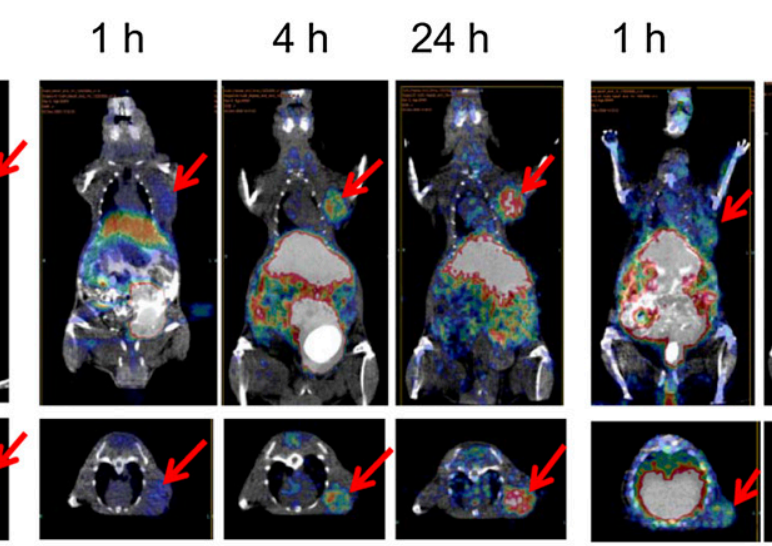

$4 \mathrm{~h}$

$24 \mathrm{~h}$

$3 \% \mathrm{ID} / \mathrm{g}$
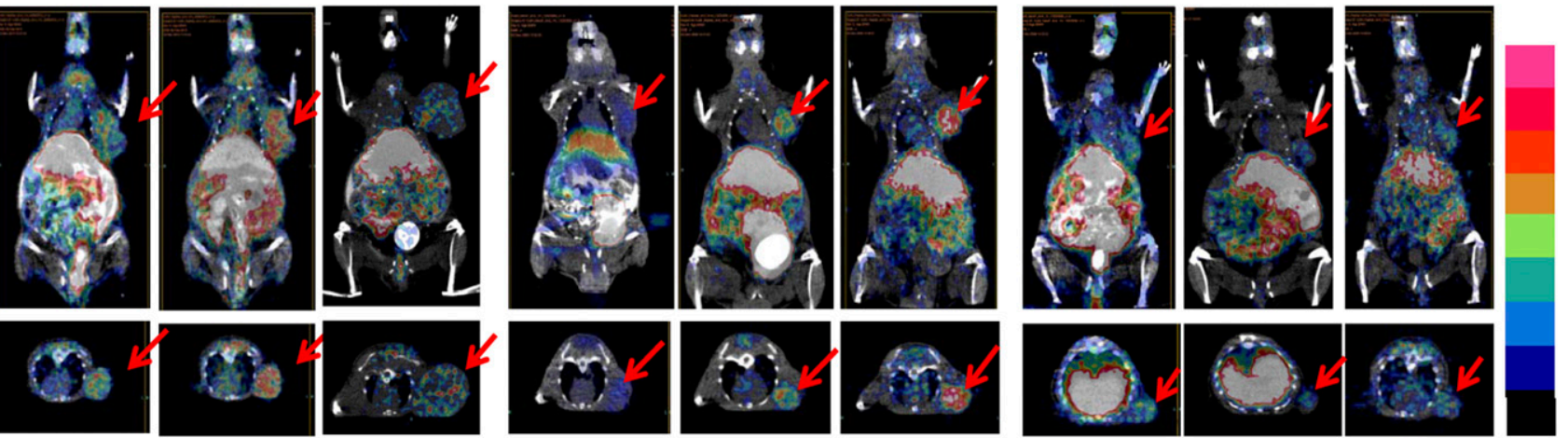

$0 \% \mathrm{ID} / \mathrm{g}$

FIGURE 4. Representative small-animal PET/CT images of mice bearing CT26, PC-3M, and A549 tumors after intravenous administration of ${ }^{64} \mathrm{Cu}$-DOTA-TNYL-RAW $(n=4)$. Arrows refer to tumors.

after injection when ${ }^{64} \mathrm{Cu}-\mathrm{DOTA}-\mathrm{TNYL}-\mathrm{RAW}$ was coinjected with cold TNYL-RAW peptide (Fig. 6B). The results of the tissue sampling study corroborated the pattern of ${ }^{64} \mathrm{Cu}$-DOTA-TNYL-RAW biodistribution determined by noninvasive in vivo PET/CT.

\section{DISCUSSION}

The widespread expression of EphB4 and other ephrin receptors in tumors has stimulated interest in exploring these receptors as targets for the development of new cancer therapies (22). The ability to identify patients with significant EphB4 receptor expression in tumors or to monitor changes in EphB4 expression during treatment using noninvasive imaging techniques would markedly enhance
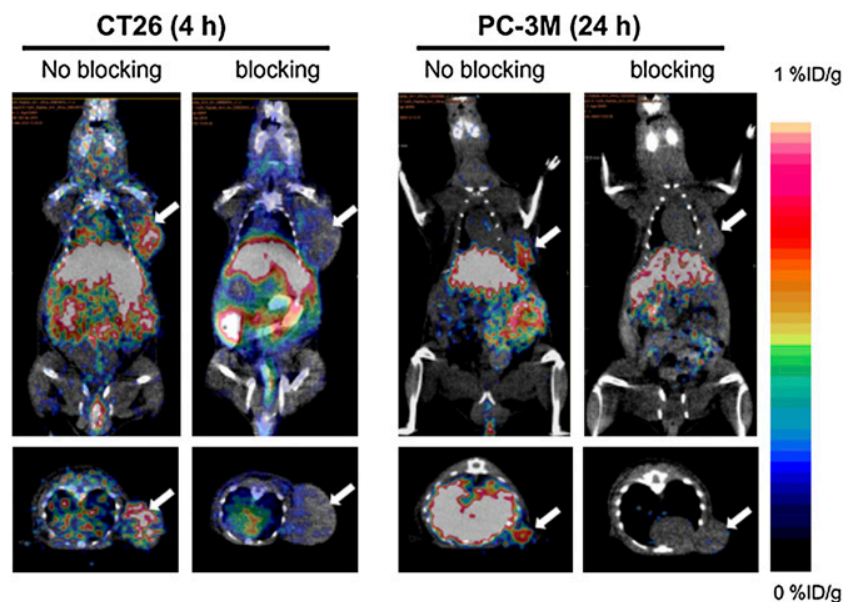

FIGURE 5. Representative small-animal PET/CT images showing blocking of ${ }^{64} \mathrm{Cu}$-DOTA-TNYL-RAW uptake in CT26 tumors at $4 \mathrm{~h}$ and in PC-3M tumors at $24 \mathrm{~h}$ after radiotracer injection. For blocking experiment, ${ }^{64} \mathrm{Cu}-\mathrm{DOTA}$-TNYL-RAW was coinjected with cold TNYL-RAW (50 $\mu \mathrm{g} / \mathrm{mouse})$. Arrows refer to tumors. the selection and evaluation of patients treated with anticancer drugs directed at EphB4. With this aim, we developed ${ }^{64} \mathrm{Cu}$-DOTA-TNYL-RAW, a PET radioligand for EphB4 receptor imaging, based on an EphB4 agonist peptide with binding to EphB4 receptors in the low nanomolar range (23).

SPR analysis showed that TNYL-RAW peptide had a $\mathrm{K}_{\mathrm{D}}$ of $3.09 \mathrm{nM}$, which is comparable to that reported in the literature $\left(\mathrm{K}_{\mathrm{D}}, 1-2 \mathrm{nM}\right)(23)$. TNYL-RAW also had a slow dissociation rate $\left(\sim 1.3 \times 10^{-3}\left[\mathrm{~s}^{-1}\right]\right)$, which is a better indicator than simple binding affinity for in vivo molecular imaging applications (26). Previous studies showed that the $\mathrm{N}$-terminal residues of the peptide could be modified without affecting the stability of the binding complex with EphB4 (27). However, when the radiometal chelator DOTA was introduced at the $\mathrm{N}$ terminus of TNYL-RAW, an 8-fold reduction in $\mathrm{K}_{\mathrm{D}}$ was observed. The introduction of $\mathrm{Cu}^{2+}$ to DOTA-TNYL-RAW restored the binding affinity of TNYLRAW (Table 1). Therefore, subtle structural change at the $\mathrm{N}$ terminus of the peptide can still affect the binding of the peptide to EphB4 receptors. Because no interaction between a scrambled peptide and EphB4 was observed, the binding of TNYL-RAW to EphB4 is sequence-specific.

Most colon cancer and prostate cancer cell lines overexpress EphB4 receptors $(16,28,29)$. Both the CT26 colon cancer and PC-3M prostate cancer cell lines used in our studies were positive for EphB4 expression (Fig. 3; Supplemental Fig. 3). Taken together, the results of our binding and uptake studies (Fig. 3; Supplemental Figs. 3 and 4) indicate that ${ }^{64} \mathrm{Cu}$-DOTA-TNYL-RAW exhibits specific, high-affinity binding to EphB4 on the surface of cancer cells, with low nonspecific interaction, making ${ }^{64} \mathrm{Cu}-$ DOTA-TNYL-RAW a suitable probe for noninvasive imaging of EPhB4 receptors.

In vivo small-animal PET/CT studies revealed that ${ }^{64} \mathrm{Cu}-$ DOTA-TNYL-RAW has favorable tumor-homing character- 


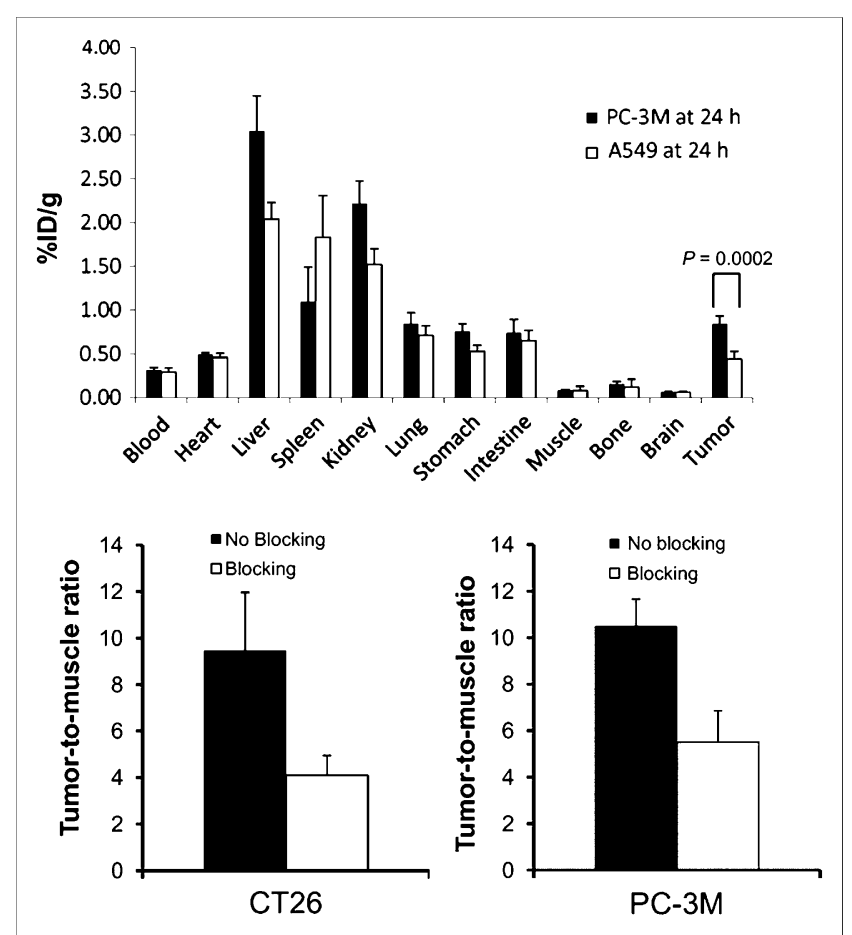

FIGURE 6. (A) Biodistribution of ${ }^{64} \mathrm{Cu}$-DOTA-TNYL-RAW in mice bearing PC-3M and A549 tumors at $24 \mathrm{~h}$ after injection. Data are presented as \%ID/g and are expressed as mean \pm SD $(n=4)$. (B) Tumor-to-muscle-uptake ratio. In blocking group, mice were injected with ${ }^{64} \mathrm{Cu}-\mathrm{DOTA}-\mathrm{TNYL}-\mathrm{RAW}(7.4 \mathrm{MBq}$ [200 $\left.\mu \mathrm{Ci}]\right)$ and cold TNYL-RAW peptide ( $20 \mu \mathrm{g} /$ mouse). Data are presented as mean \pm $\mathrm{SD}(n=6)$. Data were obtained at $4 \mathrm{~h}$ after injection in mice with CT26 tumors and at $24 \mathrm{~h}$ after injection in mice with PC-3M tumors.

istics in CT26 and PC-3M tumor xenografts in mice. In contrast, the radiotracer showed only minimal uptake in A549 tumors at all time points (Fig. 4). Ex vivo immunohistostaining of tumor xenografts confirmed that both CT26 and PC-3M tumors expressed high levels of EphB4, whereas A549 tumors had negligible EphB4 levels. In CT26 tumors, ${ }^{64} \mathrm{Cu}$-DOTA-TNYL-RAW was washed out of the tumor after $4 \mathrm{~h}$, but it was significantly retained by PC-3M tumors for up to $24 \mathrm{~h}$ (Fig. 4). Given the fact that the peptide-EphB4 complex has a relatively slow off-rate $\left(\mathrm{k}_{\text {off }}=1.31 \times 10^{-2}\right.$ $\left[\mathrm{s}^{-1}\right]$ ), the level of EphB4 receptor expression should be the predominant factor influencing the magnitude of ${ }^{64} \mathrm{Cu}-$ DOTA-TNYL-RAW accumulation and retention in tumor tissue. However, the difference in the degradation of ${ }^{64} \mathrm{Cu}-$ DOTA-TNYL-RAW peptide-based radiotracer in different tumor microenvironments may also contribute to the difference in tumor retention of the radiotracer.

The stability of radioactive compounds is critical because the molecular integrity of the radiopharmaceutical must be maintained for an adequate time in the blood circulation during biodistribution and imaging studies. ${ }^{64} \mathrm{Cu}$-DOTATNYL-RAW was stable in DMEM with $10 \%$ FBS for at least $24 \mathrm{~h}$ and was stable in mouse serum for up to $2 \mathrm{~h}$, after which slow degradation was observed. The observed metabolic degradation of the radiolabeled peptide could be attributable to proteolysis of linear peptides by plasma peptidases (30). The introduction of D-amino acid and cyclization of the peptide can usually make peptides more resistant to enzymatic degradation $(31,32)$. Studies to improve the in vivo stability of TNYL-RAW are in progress. Nevertheless, our small-animal PET/CT studies revealed that ${ }^{64} \mathrm{Cu}-$ DOTA-TNYL-RAW possess sufficient in vivo stability for tumor imaging.

To establish the specificity of tumor uptake of ${ }^{64} \mathrm{Cu}$ DOTA-TNYL-RAW in vivo, blocking studies were performed by coinjection of the radiotracer with a large excess of nonradioactive TNYL-RAW peptide. PET images revealed significant reductions in tumor uptake of ${ }^{64} \mathrm{Cu}-$ DOTA-TNYL-RAW in both CT26 and PC-3M tumors in the presence of cold TNYL-RAW (Fig. 5). Quantitative analysis of radiotracer concentration showed that tumor-tomuscle ratios were reduced $56.7 \%$ in CT26 tumors at $4 \mathrm{~h}$ after injection and $47.6 \%$ in PC-3M tumors at $24 \mathrm{~h}$ after injection when ${ }^{64} \mathrm{Cu}-\mathrm{DOTA}-\mathrm{TNYL}-\mathrm{RAW}$ was coinjected with cold TNYL-RAW peptide (Fig. 6B). These results, together with the findings that EphB4-negative A549 tumors were hardly discernible in PET images acquired with ${ }^{64} \mathrm{Cu}-$ DOTA-TNYL-RAW (Fig. 4) and that there was significantly higher uptake of ${ }^{64} \mathrm{Cu}$-DOTA-TNYL-RAW in EphB4-positive PC-3M tumors than in EphB4-negative A549 tumors (Fig. 6A), support the notion that the uptake of ${ }^{64} \mathrm{Cu}-$ DOTA-TNYL-RAW in colon and prostate cancer xenografts in mice was specific and mediated by EphB4 receptors.

The ${ }^{64} \mathrm{Cu}$-DOTA-TNYL-RAW biodistribution data obtained by both noninvasive PET/CT and by tissue sampling indicate that the liver and the kidney were the major organs for physiologic uptake and clearance of this radiotracer. In general, hepatobiliary clearance is a major route for hydrophobic peptides (33). TNYL-RAW peptide contains several hydrophobic amino acids (Asn, Ile, Leu, Phe, Pro, Ala, Trp) that could contribute to the high liver uptake of ${ }^{64} \mathrm{Cu}$-DOTA-TNYL-RAW. The high level of accumulation of the radiotracer in the kidneys may be attributed to lysosomal degradation of the peptide within renal cells (34). Therefore, future studies to optimize the imaging properties of TNYL-RAW peptides should include the optimization of their pharmacokinetics and in vivo stability.

\section{CONCLUSION}

We have successfully demonstrated for, what is to our knowledge, the first time that noninvasive small-animal PET/CT of EphB4 receptor expression is feasible with the small-molecular-weight peptide-based radiotracer ${ }^{64} \mathrm{Cu}-$ DOTA-TNYL-RAW. This radiotracer could be used for the detection of tumors expressing EphB4 receptors and for monitoring response to therapies directed against EphB4. Further assessment in additional animal models and ex vivo human specimens will be necessary to demonstrate the full potential of this radiotracer for the assessment of EphB4 expression in tumor cells. 


\section{ACKNOWLEDGMENTS}

We thank Dawn Chalaire for editing the article. This work was supported in part by the John S. Dunn Foundation and the National Natural Science Foundation of China (30830038).

\section{REFERENCES}

1. Bakker WH, Krenning EP, Reubi JC, et al. In vivo application of $\left[{ }^{111}\right.$ In-DTPA-DPhe1]-octreotide for detection of somatostatin receptor-positive tumors in rats. Life Sci. 1991;49:1593-1601.

2. Hammond PJ, Wade AF, Gwilliam ME, et al. Amino acid infusion blocks renal tubular uptake of an indium-labelled somatostatin analogue. $\mathrm{Br} \mathrm{J}$ Cancer. 1993;67:1437-1439.

3. Haubner R, Decristoforo C. Radiolabelled RGD peptides and peptidomimetics for tumour targeting. Front Biosci. 2009;14:872-886.

4. Chen J, Cheng Z, Hoffman TJ, Jurisson SS, Quinn TP. Melanoma-targeting properties of $99 \mathrm{mtechnetium-labeled} \mathrm{cyclic} \alpha$-melanocyte-stimulating hormone peptide analogues. Cancer Res. 2000;60:5649-5658.

5. Hargreaves R. Imaging substance P receptors (NK1) in the living human brain using positron emission tomography. J Clin Psychiatry. 2002;63:18-24.

6. Blower PJ, Puncher MRB, Kettle AG, et al. Iodine-123 salmon calcitonin, an imaging agent for calcitonin receptors: synthesis, biodistribution, metabolism and dosimetry in humans. Eur J Nucl Med. 1998;25:101-108.

7. Liu Y, Abendschein D, Woodard GE, et al. Molecular imaging of atherosclerotic plaque with ${ }^{64} \mathrm{Cu}$-labeled natriuretic peptide and PET. J Nucl Med. 2010;51:85-91.

8. Schottelius M, Wester H-J. Molecular imaging targeting peptide receptors. Methods. 2009;48:161-177.

9. Pasquale EB. Eph receptor signalling casts a wide net on cell behaviour. Nat Rev Mol Cell Biol. 2005;6:462-475.

10. Dodelet V, Pasquale E. Eph receptors and ephrin ligands: embryogenesis to tumorigenesis. Oncogene. 2000;19:5614-5619.

11. Noren NK, Lu M, Freeman AL, Koolpe M, Pasquale EB. Interplay between EphB4 on tumor cells and vascular ephrin-B2 regulates tumor growth. Proc Natl Acad Sci USA. 2004;101:5583-5588.

12. Erber R, Eichelsbacher U, Powajbo V, et al. EphB4 controls blood vascular morphogenesis during postnatal angiogenesis. EMBO J. 2006;25:628-641.

13. Wang HU, Chen Z-F, Anderson DJ. Molecular distinction and angiogenic interaction between embryonic arteries and veins revealed by ephrin-B2 and its receptor Eph-B4. Cell. 1998;93:741-753.

14. Xia G, Kumar SR, Stein JP, et al. EphB4 receptor tyrosine kinase is expressed in bladder cancer and provides signals for cell survival. Oncogene. 2006;25:769-780.

15. Davalos V, Dopeso H, Castano J, et al. EPHB4 and survival of colorectal cancer patients. Cancer Res. 2006;66:8943-8948.

16. Xia G, Kumar SR, Masood R, et al. EphB4 expression and biological significance in prostate cancer. Cancer Res. 2005;65:4623-4632.
17. Takai N, Miyazaki T, Fujisawa K, Nasu K, Miyakawa II. Expression of receptor tyrosine kinase EphB4 and its ligand ephrin-B2 is associated with malignant potential in endometrial cancer. Oncol Rep. 2001;8:567-573.

18. Kumar SR, Scehnet Jeffrey S, Ley Eric J, et al. Preferential induction of EphB4 over EphB2 and its implication in colorectal cancer progression. Cancer Res. 2009;69:3736-3745.

19. Stephenson S-A, Slomka S, Douglas E, Hewett P, Hardingham J. Receptor protein tyrosine kinase EphB4 is up-regulated in colon cancer [abstract]. BMC Mol Biol. 2001;2:15.

20. Kumar SR, Singh J, Xia G, et al. Receptor tyrosine kinase EphB4 is a survival factor in breast cancer. Am J Pathol. 2006;169:279-293.

21. Noren NK, Foos G, Hauser CA, Pasquale EB. The EphB4 receptor suppresses breast cancer cell tumorigenicity through an Abl-Crk pathway. Nat Cell Biol. 2006;8:815-825.

22. Noren NK, Pasquale EB. Paradoxes of the EphB4 receptor in cancer. Cancer Res. 2007;67:3994-3997.

23. Koolpe M, Burgess R, Dail M, Pasquale EB. EphB receptor-binding peptides identified by phage display enable design of an antagonist with ephrin-like affinity. J Biol Chem. 2005;280:17301-17311.

24. Cooper MA. Optical biosensors in drug discovery. Nat Rev Drug Discov. 2002;1:515-528

25. Bauer C, Bauder-Wuest U, Mier W, Haberkorn U, Eisenhut M. ${ }^{131}$ I-labeled peptides as caspase substrates for apoptosis imaging. J Nucl Med. 2005;46: 1066-1074.

26. Berezov A, Zhang H-T, Greene MI, Murali R. Disabling ErbB receptors with rationally designed exocyclic mimetics of antibodies: structure-function Analysis. J Med Chem. 2001;44:2565-2574.

27. Chrencik JE, Brooun A, Recht MI, et al. Structure and thermodynamic characterization of the ephB4/ephrin-B2 antagonist peptide complex reveals the determinants for receptor specificity. Structure. 2006;14:321-330.

28. Liu W, Ahmad SA, Jung YD, et al. Coexpression of ephrin-Bs and their receptors in colon carcinoma. Cancer. 2002;94:934-939.

29. Huang X, Yamada Y, Kidoya H, et al. EphB4 overexpression in B16 melanoma cells affects arterial-venous patterning in tumor angiogenesis. Cancer Res. 2007;67:9800-9808.

30. Jain RK. Delivery of molecular and cellular medicine to solid tumors. J Control Release. 1998;53:49-67.

31. Hong SY, Oh JE, Lee K-H. Effect of D-amino acid substitution on the stability, the secondary structure, and the activity of membrane-active peptide. Biochem Pharmacol. 1999;58:1775-1780.

32. Shibata K, Suzawa T, Soga S, et al. Improvement of biological activity and proteolytic stability of peptides by coupling with a cyclic peptide. Bioorg Med Chem Lett. 2003;13:2583-2586.

33. Rusckowski M, Qu T, Gupta S, Ley A, Hnatowich DJ. A comparison in monkeys of ${ }^{99 \mathrm{~m}}$ Tc labeled to a peptide by 4 methods. J Nucl Med. 2001;42:18701877 .

34. Tsai SW, Li L, Williams LE, Anderson AL, Raubitschek AA, Shively JE. Metabolism and renal clearance of ${ }^{111}$ In-labeled DOTA-conjugated antibody fragments. Bioconjug Chem. 2001;12:264-270. 